\title{
Three Tuberculosis Spondylitis Patients with Resistant Rifampicin from The Transpedicular Debridement Surgery Network

\author{
Yenny Widowati ${ }^{1}$, Yani Jane ${ }^{1}$, Suryanti Dwi $P^{1}$, Syaifullah Asmiragani2 \\ ${ }^{1}$ Department of Pulmonology and Respiratory Medicine Department, Saiful Anwar General Hospital, Brawijaya University \\ ${ }^{2}$ Department of Orthopaedic and Traumatology, Saiful Anwar General Hospital, Brawijaya University
}

\begin{abstract}
Background: TB spondylitis is a disease that can cause neurological disorders, ranging from 1-2\% of the total cases of tuberculosis where the most frequent infection is the spine followed by other large joints such as hips, knees and shoulders. The increase in TB spondylitis associated with MDR TB in 2015 showed 52\% or about 32,000 incidences globally.Collaboration of individual alloy MDR TB therapy with surgery in TB spondylitis can reduce patient mortality and morbidity.

Case: We report three cases of patients in 2017-2018 in Dr. Saiful Anwar with complaints of back pain and lumps in the back, from the results of anamnesa, physical examination and supporting examination of patients diagnosed with TB spondylitis, patients were given medical management, operative and rehabilitation.

Conclusion: This case is interesting because from the results of Molecular Rapid Tests whose samples were obtained from a biopsy of the transpendicular debridement surgery tissue obtained the results of Resistant Rifampicin, all three patients received individualized OAT treatment, the development of the conditions of the three patients improved and quality of life improved.
\end{abstract}

Keywords: Rifampicin-resistant TB spondylitis, individual regimen, quality of life

MRJ 2021; 3(1):148-156

\section{Introduction}

Tuberculous spondylitis

(TB

spondylitis) is an infectious disease of the spine that can be very destructive because it has the potential to increase morbidity, including permanent neurological deficits and severe deformities. The infection process damages the body of the vertebral column and if it attacks the spinal cord, it causes the patient to experience paralysis and loss of sensation in the lower leg to the level of the area where the nerve is affected (1). TB spondylitis is a chronic granulomatous inflammatory disease of the spine caused by the bacterium Mycobacterium tuberculosis. As many as $50 \%$ of patients with TB spondylitis have spinal lesions and 10-45\% of them have neurological deficits. If this Mycobacterium tuberculosis bacterial infection affects the vertebral body, the

\footnotetext{
*Corresponding author:

Yenny Widowati (yennyedy@student.ub.ac.id)

Department of Pulmonology and Respiratory Medicine, RSUD Dr. Saiful Anwar Malang - Universitas Brawijaya, Jaksa Agung Suprapto St. No. 2, Malang.65112, Indonesia
} 
damage that occurs causes spinal instability and disruption of the surrounding structures. Patients may experience paralysis due to compression of the spinal cord. Tuberculous spondylitis can come from direct (primary) infection, ie bacteria directly infect the body or indirect (secondary) infection, ie bacteria spread hematogenous or lymphogenously from infection sites elsewhere to the spinal cord. Most TB spondylitis is a secondary infection of the lungs, but in some cases, it is a primary infection (2).

The report released by WHO in 2019 stated that extrapulmonary TB in 2018 infected $15 \%$ of the total 7 million cases found. $1-2 \%$ of the total tuberculosis cases in the world is TB spondylitis. About $5 \%$ of TB cases in Indonesia have TB spondylitis. In the United States, the prevalence of TB spondylitis is about $3.7 \%$ of all tuberculosis cases. Men experience TB spondylitis more often than women with a ratio of $1.5-2$ times (Hidalgo et al., 2018). Approximately $95 \%$ of pyogenic infections involve the intervertebral bodies and discs, only about 5\% involve the posterior elements of the vertebrae. The level of the affected vertebra varies and infection has been reported to occur at any level of the vertebra. The most common sites were the lumbar vertebrae (45-50\%), followed by the thoracic vertebrae $(35 \%)$, cervical $(3-20 \%)$, and the sacral region (3).

The growth of Mycobacterium tuberculosis bacteria on the bone will cause infection and inflammatory response in the host. Mycobacterium tuberculosis infection will cause macrophage apoptosis that produces cathepsin $\mathrm{D}$ which is involved in tissue damage and the liquefaction process of granulomas. The first reaction to tuberculosis infection in the spine occurs in the RES system of the vertebral body in the form of accumulation of polymorphonuclear cells (PMN) which are immediately replaced by macrophages and monocytes. Lipids produced by the process of phagocytosis of tuberculosis bacilli by macrophages will be released through the cytoplasm of macrophages and form epithelioid cells (data Langhans) and case necrosis which gives an overview of the body's specific reaction to Mycobacterium tuberculosis bacterial infection (4).

The spread of bacterial infection in TB spondylitis is generally hematogenous through arteries or veins. The initial focus of infection is in the anterior portion of the vertebra near the subchondral bone, which has extensive arterial and venous plexus anastomoses. The intervertebral disc is an avascular structure so that it is initially 
protected from infection. As the infection progresses, adjacent vertebrae are eventually infected through vascular contact and subligamentous pathways. When only one vertebra is involved, the disc receives nutrition from the adjacent normal vertebra and remains normal. However, involvement of two adjacent vertebrae hinders food intake of the intervertebral disc leading to destruction and displacement (2).

\section{Case}

The list of temporary problems in the three patients can be seen in Table 1 below:

Table 1. First Problem List

\begin{tabular}{|c|c|c|c|}
\hline $\begin{array}{c}\text { Temporary } \\
\text { problem }\end{array}$ & $\begin{array}{l}\text { Mrs. S (50 } \\
\text { years old) }\end{array}$ & $\begin{array}{c}\text { Mr. } M \\
(35 \text { years } \\
\text { old })\end{array}$ & $\begin{array}{c}\text { Mrs. D } \\
\text { (33 years) }\end{array}$ \\
\hline Anamnesa & $\begin{array}{l}\text { Back pain } \\
\text { radiating } \\
\text { down to } \\
\text { both legs } \\
\text { accompanie } \\
d \text { by a } \\
\text { painful lump } \\
\text { in the back }\end{array}$ & $\begin{array}{l}\text { Back pain } \\
\text { accompanie } \\
d \text { by } \\
\text { cramping } \\
\text { and tingling } \\
\text { in both legs } \\
\text { so that the } \\
\text { patient } \\
\text { cannot get } \\
\text { out of bed, a } \\
\text { lump in the } \\
\text { back that } \\
\text { hurts when } \\
\text { the patient } \\
\text { bends down }\end{array}$ & $\begin{array}{l}\text { Back pain is } \\
\text { accompanie } \\
\mathrm{d} \text { by tingling } \\
\text { and painful } \\
\text { lumps in the } \\
\text { back so that } \\
\text { the patient } \\
\text { cannot walk }\end{array}$ \\
\hline $\begin{array}{l}\text { Physical } \\
\text { examination }\end{array}$ & $\begin{array}{l}\text { abscess in } \\
\text { the posterior } \\
\text { thoracic } \\
\text { region }\end{array}$ & $\begin{array}{l}\text { abscess in } \\
\text { posterior } \\
\text { thoracic } \\
\text { region, } \\
\text { kyphosis (+) }\end{array}$ & $\begin{array}{l}\text { abscess in } \\
\text { posterior } \\
\text { thoracic } \\
\text { region, } \\
\text { kyphosis (+) }\end{array}$ \\
\hline $\begin{array}{l}\text { OAT } \\
\text { treatment } \\
\text { history }\end{array}$ & $\begin{array}{l}\text { OAT } \\
\text { category I: } \\
\text { December } \\
2016 \text { - } \\
\text { March } 2017 \\
\text { (4 months, } \\
\text { stopped } \\
\text { because of } \\
\text { nausea and } \\
\text { vomiting) } \\
\text { OAT }\end{array}$ & $\begin{array}{l}\begin{array}{l}\text { OAT } \\
\text { category } \\
\text { starting }\end{array} \\
\text { April } \\
2018\end{array}$ & $\begin{array}{lr}\text { OAT } & \\
\text { category } & \text { I: } \\
\text { from } & 29 \\
\text { October } & \\
2018 & \end{array}$ \\
\hline
\end{tabular}

\begin{tabular}{|c|c|c|c|}
\hline & $\begin{array}{l}\text { category II: } \\
\text { April 2017- } \\
\text { June } 2017 \text { (2 } \\
\text { months, } \\
\text { stopped } \\
\text { because of } \\
\text { nausea and } \\
\text { vomiting) }\end{array}$ & & \\
\hline CXR & $\begin{array}{l}\text { minimal } \\
\text { pulmonary } \\
\text { TB }\end{array}$ & $\begin{array}{l}\text { Active } \\
\text { pulmonary } \\
\text { TB far } \\
\text { advanced } \\
\text { lesion }\end{array}$ & Pneumonia \\
\hline $\begin{array}{l}\text { Thoraco } \\
\text { Lumbar } \\
\text { Plain Photo }\end{array}$ & $\begin{array}{l}\text { There is a } \\
\text { lytic lesion } \\
\text { in the } \\
\text { anterosuperi } \\
\text { or L4 } \\
\text { vertebral } \\
\text { body with } \\
\text { narrowing } \\
\text { of the } \\
\text { intervertebr } \\
\text { al space } \\
\text { suspect } \\
\text { spondylodis } \\
\text { citis, } \\
\text { thoracolumb } \\
\text { ar } \\
\text { spondylosis }\end{array}$ & $\begin{array}{l}\text { Compressio } \\
\mathrm{n} \text { fracture is } \\
\text { seen at L3 } \\
\text { Spondylolist } \\
\text { hesis L2, L3, } \\
\text { L4 }\end{array}$ & - \\
\hline MRI & $\begin{array}{l}\text { Pyogenic } \\
\text { susp } \\
\text { spondylodis } \\
\text { citis at the } \\
\text { level of the } \\
\text { Th 12-L4 } \\
\text { vertebrae } \\
\text { with } \\
\text { intraosseous } \\
\text { abscess, } \\
\text { right and left } \\
\text { psoas } \\
\text { abscess, and } \\
\text { M. erector } \\
\text { spine } \\
\text { (posterior } \\
\text { paravertebra } \\
\text { 1) abscess } \\
\text { Mild spinal } \\
\text { canal } \\
\text { stenosis and } \\
\text { moderate } \\
\text { bilateral } \\
\text { paramedian } \\
\text { stenosis at } \\
\text { level L3/4 ec } \\
\text { disc } \\
\text { protrusion }+ \\
\text { spondylosis } \\
+ \\
\text { ligamentum } \\
\text { flavum }\end{array}$ & $\begin{array}{l}\text { According } \\
\text { to } \\
\text { tuberculous } \\
\text { spondylodis } \\
\text { citis at the } \\
\text { level of the } \\
\text { L2-L3 } \\
\text { vertebrae, } \\
\text { which are } \\
\text { paravertebra } \\
\text { l abscesses } \\
\text { with an } \\
\text { extradural } \\
\text { mass and } \\
\text { extending to } \\
\text { the psoas } \\
\text { muscle } \\
\text { bilaterally, } \\
\text { severely } \\
\text { constricting } \\
\text { the spinal } \\
\text { canal to that } \\
\text { level. }\end{array}$ & $\begin{array}{l}\text { Supporting } \\
\text { suspected } \\
\text { spondylodis } \\
\text { citis etc } \\
\text { vertebral TB } \\
\text { L1-L2 with } \\
\text { left } \\
\text { dominant } \\
\text { bilateral } \\
\text { PSOAS } \\
\text { abscess } \\
\text { volume } \pm \\
198 \text { cc with } \\
\text { spinal canal } \\
\text { involvement } \\
\text { at levels T } \\
12 \text { to T3 }\end{array}$ \\
\hline
\end{tabular}




\begin{tabular}{|c|c|c|c|}
\hline & $\begin{array}{l}\text { hypertrophy } \\
\text { Bulging } \\
\text { broad base } \\
\text { at level } \\
\text { L2/3,L4/5,L } \\
5 / \mathrm{S} 1\end{array}$ & & \\
\hline $\begin{array}{l}\text { TCM } \\
\text { sputum }\end{array}$ & $\begin{array}{l}\text { MTB } \\
\text { detected } \\
\text { medium } \\
\text { (Rifampicin } \\
\text { Resistant } \\
\text { Detected) }\end{array}$ & - & $\begin{array}{l}\text { MTB } \\
\text { detected } \\
\text { very low } \\
\text { (Rifampicin } \\
\text { Resistant } \\
\text { Detected) }\end{array}$ \\
\hline Pus Culture & $\begin{array}{l}\text { No bacterial } \\
\text { colony } \\
\text { growth } \\
\text { (aerobic) } \\
\text { was found. }\end{array}$ & $\begin{array}{l}\text { No bacterial } \\
\text { colony } \\
\text { growth } \\
\text { (aerobic) } \\
\text { was found. }\end{array}$ & $\begin{array}{l}\text { Staphylococ } \\
\text { cus } \\
\text { Coagulase } \\
\text { Negative }\end{array}$ \\
\hline $\begin{array}{l}\text { Individually } \\
\text { Alloy OAT }\end{array}$ & $\begin{array}{l}\text { starting June } \\
14, \quad 2017 \\
\text { with } \\
\text { regimen } \\
\mathrm{Cm} / \mathrm{Cs} / \mathrm{Eto} / \\
\mathrm{Lfx} / \mathrm{Z} / \mathrm{B} 6\end{array}$ & $\begin{array}{l}\text { starting } 12 \\
\text { June } 2018 \\
\text { with } \\
\mathrm{Cm} / \mathrm{Cs} / \mathrm{E} / \mathrm{Et} \\
\text { o/Km/Lfx/Z } \\
\text { /B6 regimen }\end{array}$ & $\begin{array}{l}\text { starting } 10 \\
\text { December } \\
2018 \quad \text { with } \\
\text { Clf/Cs/E/K } \\
\text { m/Lfx/B6 . } \\
\text { regimen }\end{array}$ \\
\hline $\begin{array}{l}\text { OAT side } \\
\text { effects }\end{array}$ & $\begin{array}{l}\text { Nausea } \\
\text { vomiting, } \\
\text { Hypokalemi } \\
\text { a } \\
\text { Hyperurice } \\
\text { mia, } \\
\text { Increased } \\
\text { creatinine } \\
\text { clearance, } \\
\text { Mild right } \\
\text { ear } \\
\text { conduction } \\
\text { hearing loss }\end{array}$ & $\begin{array}{l}\text { Hypokalemi } \\
\text { a } \\
\text { Ears ringing }\end{array}$ & $\begin{array}{l}\text { DILI } \\
\text { Hypokalemi } \\
\text { a }\end{array}$ \\
\hline $\begin{array}{l}\text { End of } \\
\text { individualiz } \\
\text { ed combined } \\
\text { OAT } \\
\text { treatment }\end{array}$ & $\begin{array}{l}\text { February 22, } \\
2019\end{array}$ & $\begin{array}{l}\text { March 3, } \\
2020\end{array}$ & $\begin{array}{l}\text { August } \\
2020\end{array}$ \\
\hline
\end{tabular}

From Table 1 above, the list of fixed problems in the three patients is $\mathrm{TB}$ spondylitis with vertebral abscess, Rifampicin-resistant TB (from the Transpedicular Debridement Operation Network, the results of TCM of pus tissue show Rifampicin Resistant).
Based on the data above, the three patients with different characteristics of clinical data and the results of supporting examinations were diagnosed with RR TB spondylitis who received medical management in the form of a combination of individual OAT and operative action according to the neurological deficit experienced by the patient.

\section{Discussion}

In the case report, it was reported that three patients with differences in age and sex, namely women aged 50 years and 33 years and men aged 35 years had complaints of back pain with lumps on the back. From the results of anamnesis, physical examination, and supporting the three patients diagnosed with TB spondylitis. Based on the epidemiological theory, the majority of TB spondylitis is experienced by people of productive age, namely $15-54$ years, this is following the literature and the presentation of reported cases. The prevalence of men experiencing TB spondylitis more often than women with a ratio of $1.5-2$ times. This is of course slightly different from the case report presented because in the 2017-2019 period at dr. Saiful Anwar Hospital, Malang, there were 3 cases of MDR TB Spondylitis patients with the incidence of women being 
reported more than men. are socio-economic history and education level, previous history of OAT treatment, densely populated environmental conditions (5).

Back pain is one of the causes of patients coming to health care facilities, this statement is following the conditions experienced by the three patients. In the early stages, they complained of back pain that radiated down to both legs accompanied by cramps and tingling which gradually made the patient unable to walk because his legs felt weak and resulted in paralysis. This back pain experienced causes neurological deficits due to nerve involvement. Initial symptoms may include radicular pain around the spine that radiates to the chest or abdomen, followed by paraparesis which gradually worsens into paraplegia. Tapping pain and motor disturbances are found in cases of tuberculous spondylitis that have involved the deformity and the presence of nerve compression (6).

The growth of Mycobacterium tuberculosis bacteria on the bone will cause infection and inflammatory response in the host. Lipids produced by the process of phagocytosis of tuberculosis bacilli by macrophages will be released through the cytoplasm of macrophages and form epithelioid cells (data Langhans) and case necrosis which gives an overview of the body's specific reaction to Mycobacterium tuberculosis bacterial infection including systemic symptoms such as weight loss, decreased appetite, and night sweats. This is following the systemic conditions experienced by the three patients, they complained of significant weight loss, the appearance of cold sweats at night. The nutritional adequacy factor is also an equally important concern so that patients with TB spondylitis need good nutritional intake for the recovery period (4).

A lump on the back that forms an abscess can push backward, compressing the spinal cord and causing paraplegia. In addition to pressure abscess, early paraplegia can also be caused by damage to the spinal cord due to vascular disorders or due to continuous stretching of the gibbous which is called advanced paraplegia. The theory above is following what was experienced by the three patients. The lump, which increases in size, will gradually cause the infected vertebral body to collapse, which can then penetrate the vertebral cortex and infect the surrounding soft tissue, causing a painful sensation. One of the physical examination steps that the patient can perform is by bending over. Two of the three patients reported feeling intense pain when asked by 
doctors to bend their back. Mr. M's patient did not feel pain in his back lump, this may be due to the patient's high pain threshold. When viewed from the history of the other two patients, namely Mrs. S and Mrs. D, they have a history of trauma to the spine due to traumatic factors (5).

MRI examination is the gold standard because it can differentiate between tuberculous spondylitis and pyogenic spondylitis. The presence of a well-defined mass with abnormal signal intensity in the paraspinal region, suggesting an abscess with a thin and regular wall, spread through the sub-ligaments at three or more vertebral levels, multiple vertebrae, or involvement of the entire body are findings suggestive of tuberculous spondylitis rather than pyogenic spondylitis. . In addition, the presence of skip lesions and cold paraspinal abscesses also leads to TB spondylitis. Based on the MRI results, Mrs. S showed pyogenic spondylodiscitis susp at the level of the Th 12-L4 vertebrae with intraosseous abscess, right and left psoas abscess and M. erector spinal abscess (posterior paravertebral), the results of MRI lumbosacral $\mathrm{Mr} . \mathrm{M}$ is a paravertebral abscess that extends widely to M. psoas bilaterally, narrowing the spinal canal, while MRI Mrs. D showed suspected spondylodiscitis etc TB vertebra L1-L2 with
PSOAS abscess bilateral left dominant volume $\pm 198 \mathrm{cc}$ with spinal canal involvement at level T12 to T3. Judging from the literature above, the MRI examination is following the clinical evidence experienced by the three patients (7).

The vertebral level affected by spondylitis varies and infection has been reported to occur at any vertebral level. The most common sites were the lumbar vertebrae $(45-50 \%)$, followed by the thoracic vertebrae $(35 \%)$, cervical $(3-20 \%)$, and the sacral region. The case report presented is following the literature, where all three patients reported a predilection for spondylitis in the lumbar spine (based on MRI results). Two patients, Mrs. S and Mrs. D reported that their spondylitis also affected the thoracic region (3).

The amount of sputum for diagnosis (TCM) is 2 sputum with good quality, namely one sputum for TCM examination, and one sputum as a backup if a repeat examination is needed. TCM examination for non-phlegm specimens can be obtained from preparations such as cerebrospinal fluid (CSF), biopsy tissue, gastric lavage, gastric fluid aspiration, and lymph nodes. The diagnostic sensitivity of the TCM examination is $75-80 \%$, while the specificity is $100 \%$. The results of the TCM examination 
of the sputum specimen and the biopsy tissue of Mrs. S showed MTB detected medium (Rifampicin Resistant Detected), Mr. M from the results of the TCM examination of the biopsy tissue, MTB was detected low (Rifampicin Resistant Detected), while Mrs. D of the sputum sample shows MTB detected very low (Rifampicin Resistant Detected) from the results of the MTB biopsy tissue sample detected low (Rifampicin Resistant Detected). Based on the results of the bacteriological examination, the three patients above showed MDR TB spondylitis where the TB bacilli were resistant to Isoniazid and Rifampicin simultaneously, with or without being followed by resistance to other first-line drugs.

Medical therapy alone can improve neurological deficits. Each case must be assessed individually. Clinical improvement is generally achieved within 3 months if therapy is successful. The latest recommendations for the treatment of MDRTB, namely with a combination of 5 drugs, include:

1. One of the first-line drugs known to be sensitive through the results of resistance culture,

2. OAT injection for a minimum period of 6 months,

3. Quinolones,
4. Cycloserine or ethionamide,

5. Other antibiotics such as amoxicillinclavulanate and clofazimine. The duration of OAT administration is at least 18-24 months (8). Based on the data we see above, it shows that all three patients have used the individual OAT recommendations according to the literature. The side effects that occurred in the three patients were well managed, according to the results of the TAK decision.

In patients who are planning for surgery, OAT must still be given, at least 10 days before surgery OAT must have been given. The three patients above were reported to be given a combination of OAT before surgery, this is following the literature. The indications for surgery are acute neurologic deficits such as paraplegia or paraparesis, unstable spinal deformities, or accompanied by pain such as kyphosis $\left(30^{\circ}\right.$ for adults, $15^{\circ}$ for children), extensive abscesses are present, percutaneous biopsy fails to diagnose and is found. severe pain due to compression of the abscess, complete sensory loss, or impaired motor strength for more than 6 months. In the case of Mrs. S performed Transpendicular Debridement followed by the installation of a body jacket. Meanwhile, in Mr. M's case, laminectomy was performed with decompression, post debridement stabilization, and instrumented posterolateral 
fusion, Mrs. D's case with Transpendicular Lumbar Debridement III, Lumbar II-III Laminectomy + posterolateral fusion on Thoracal XII-L1,4,5.

Drainage of the abscess can prevent worsening neurological symptoms and vertebral collapse. After the formation of an abscess (cold abscess) and degeneration of the two discs, drainage should be performed. Due to the presence of extensive abscesses in all three patients, debridement was performed with the aim of decompression of the spinal cord and evacuation of the abscess. This is in accordance with the existing literature. The advantages of posterior instrumentation over anterior are the ease of reaching the target area and the small possibility of nerve disturbances. In addition, the posterior approach also provides good control in the sagittal plane of the spinal column. Posterior fixation is performed to correct the kyphosis and ensure long-term stability of the spine in the sagittal line. The weakness of posterior instrumentation is the disruption of the contour of the back muscles, so the three patients underwent posterior fixation to maintain spinal stability, followed by the stage of medical rehabilitation.

\section{Conclusion}

Tuberculous spondylitis is the most dangerous form of musculoskeletal tuberculosis because it can cause bone destruction, deformity, and paraplegia. Suspicion of TB spondylitis is directed at patients who come with complaints of nonspecific back pain, kyphotic deformity, spinal cord compression, and neurological deficits. Treatment of TB spondylitis is generally divided into two parts, namely medical and surgical. Medical therapy is preferred, in this case, the use of OAT must be monitored closely to prevent the emergence of multiresistant strains. While surgical therapy complements medical therapy and is adjusted to the individual circumstances of each patient.

This case is interesting to report because the incidence of TB spondylitis with MDR strains is quite rare, with the combination of individual OAT therapy, surgery, and rehabilitation bringing quite encouraging results to the quality of life of these three patients. A careful diagnosis coupled with proper management, as well as psychological support from the family, community, and team from Panter (Never Give Up) Malang area can reduce the number of disabilities and patient morbidity.

\section{References}

1. Rajasekaran S, Soundararajan DCR, Shetty AP, Kanna RM. Spinal Tuberculosis: Current Concepts. Glob 
Spine J. 2018;8(4_suppl):96S-108S.

2. Mak KC, Cheung KMC. Surgical treatment of acute TB spondylitis: Indications and outcomes. Eur Spine J. 2013;22(SUPPL.4):603-11.

3. Lee KY. Comparison of pyogenic spondylitis and tuberculous spondylitis. Asian Spine J. 2014;8(2):216-23.

4. Arockiaraj J, Michael JS, Amritanand R, David KS, Krishnan V. The role of Xpert MTB/RIF assay in the diagnosis of tubercular spondylodiscitis. Eur Spine J. 2017;26(12):3162-9.

5. Rasouli MR, Mirkoohi M, Vaccaro AR, Yarandi KK, Rahimi-Movaghar V. Spinal tuberculosis: Diagnosis and management. Asian Spine J. 2012;6(4):294-308.

6. Pang X, Shen X, Wu P, Luo C, Xu Z,
Wang X. Thoracolumbar spinal tuberculosis with psoas abscesses treated by one-stage posterior transforaminal lumbar debridement, interbody fusion, posterior instrumentation, and postural drainage. Arch Orthop Trauma Surg. 2013;133(6):765-72.

7. Currie S, Galea-Soler S, Barron D, Chandramohan M, Groves C. MRI characteristics of tuberculous spondylitis. Clin Radiol [Internet]. 2011;66(8):77887. Available from: http://dx.doi.org/10.1016/j.crad.2011.02. 016

8. Kemenkes RI. pedoman SUN. 2015;i100. 